periods, two with both ureters in the rectum. These experiments in detail will form a subject for a further communication.

\section{SCHOTT TREATMENT OF CHRONIC HEART DISEASE}

WITH REPORT OF CASES.

Read before the Medical Society of the City Hospital Alumni, of St. Louis, Nov. 3, 1898.

BY ELSWORTH SMITH, JR., A.M., M.D.

INSTRCCTOR IN PHYSICAL DIAGXOSIS, AND PHYSICIAN MEDICAL CLINIC, ST. LOLIS MEDICAL COLLEGE, MEDICAL DEPARTMENT OF WASH INGTON LNIVIERITY; CONSULTING PHYSICIAN, ST. LOUIS CITY FOSPITAL. sT. LOUIS, Mo.

By way of preface, I should like to recall certain fundarnental principles in the management of diseases of the heart upon which rests the rationale of this method of treatment by baths and gymnastic movements. At the outset it is important for us to distinctly remember of how slight importance, from a prognostic standpoint, is a valve lesion, as evidenced by a murmur and the other physical signs, for the discovery of such a lesion does not in itself consign the victim to a certain or early grave any more than it does per se call for the administration of the class of remedies known as cardiac stimulants. Indeed, many persons with marked physical evidence of valvular defects live out actively and usefully their allotted life expectancies, uninfluenced apparently by these cardiac maladies. Lauder Brunton relates that when he was a student of medicine, one of his professors was the subject of adherent pericardium, and conse. quent dyspnea, but is now quite strong and well after thirty-five years of professional work. Balfour states that many cases of aortic regurgitation run along comfortably and perfectly free of symptoms for thirty or forty years, and one of his friends, the subject of mitral regurgitation from the age of 30 years, led an active and useful life up to his death, at the age of 70 years; but these are but two of innumerable such examples which go to prove that the destiny of a case of valvular disease of the heart does not depend upon the valve lesion itself, so that we must look elsewhere for the pernicious results that do often occur in these cases; and in so doing we discover that it is the condition of the heart muscle which determines the future course of these cases. So long as the cardiac muscle remains sufficiently strong to carry on the circulation in spite of valve defects, just so long will the patient be perfectly comfortable and entirely free of symptoms, he having then, as we say, a compensated heart lesion; but allow this muscle to grow weak from any cause, to become, for example, the seat of fatty degeneration, then it will soon find itself unable to propel the proper amount of blood beyond the obstruction into the arterial system; resulting in damming up of the vital fluid in the venous trunks, and giving rise sooner or later to the picture of an uncompensated heart lesion, with which we are all so familiar.

We may, therefore, say the treatment of chronic heart disease practically resolves itself into the proper development and care of a muscle; and how does the athlete acquire his powerful muscles? Simply by a process of training, with the object, through a nutritious diet, of supplying his entire system, muscles included, with a sufficient quantity of rich, arterial blood, so that by systematic, regulated exercise he may cause his muscles to enlarge or hypertrophy, and thereby gradually become capable of doing more and more work. Perfectly analogous to this should be the care of the heart muscle, called upon through disease to do extra work; and in reality this is just what, and only what, the subject of beginning cardiac disease needs. He must be enabled through attention to rules of hygiene, proper diet, etc., to supply his heart with an abundance of good, rich blood, and through properly regulated exercise, he must gradually accustom his heart muscle to meet the increasing demands on its force and strength. This is the only medication such a case should receive during the formative stage of compensation, and even afterward, in maintaining this condition of compensation in a comparatively healthy heart muscle. We should be no more justified in giving heart stimulants or tonies to such a case than we would be in beating the animal which is faithfully drawing along a heavily laden wagon; for in either case we would be doing more harm than good.

A striking example of the capabilities of muscular power through training is the classic one of the wrestler of Milo, who, it is said, was able to carry about a bull by beginning to carry him as a calf, and continuing to do so daily from that time until grown. On the other hand, in one devoid of gymnastic training, a sudden great effort beyond what has been his custom, may cause distress and dyspnea; so we see the strength of the cardiac and other muscles is, in fact, largely relative, and stands in relation to the work ordinarily demanded of them. The heart muscle also resembles those of the athlete in that they all require a definite amount of rest to prevent their becoming fatigued. This all-important fact is very graphically put by Brunton as follows: "To walk one thousand miles in six weeks can hardly be called any feat at all; but to walk one thousand miles in a thousand hours is a very different proposition, and may be regarded even now as beyond the capacity of most men. There is no more actual work involved in walking twentyfour miles in one day than in walking twenty-four successive hours, one mile for every hour, the difference between the two being the short period allowed for rest and recuperation between each period of exertion in the latter. Now, the action of the heart is like that of the athlete who has very short periods of rest between his periods of action, and just as the athlete's work is rendered more difficult by shortening his period of rest, so is that of the heart by increasing the rapidity of its pulsation."

In order, however, to thoroughly appreciate this very apt comparison of Brunton, we should recall for a moment how the heart obtains its rest. The cycle of its action is, as you know, divided into systole, diastole and pause, and it is during the two latter periods that the ventricles, the most important muscles of the heart, secure their much-needed rest. Should the action of the organ be accelerated, what is the result? Why, the time occupied by the systole remains as great as ever, while that of the diastole and pause is shortened, so that abnormal rapidity of the heart always means that the organ is doing more work with less rest-a condition in which we nearly always find it in disease.

This résumé of fundamental principles would, how. ever, be incomplete without a few words concerning the manner in which the muscles of the heart are nourished, without recalling, for example, that the nourishing fluid is carried to them through the two 
coronary arteries. Now the blood probably enters these channels most freely during the diastole and pause because of the obstruction during the systole offered by the contraction of the ventricular walls, and the consequent compression of the lumen of these vessels and their branches, which, while it may favor the distribution of the blood already within them, must, nevertheless, offer a serious impediment to the inflow of a fresh supply from the aorta. How much more rational it would appear to suppose that these coronary vessels receive their greatest influx of blood during the diastole, for then, through the relaxation of the ventricular muscles, their lumen would be entirely patent. Certainly, the tension in the aorta, which is then high enough to, as a rule, close the aortic flaps with force, would naturally then be sufficiently high to overcome the pressure in the coronary artery. It would seem natural, therefore, to conclude that the quantity of blood going to the ventricular muscles would be largely measured by the length of the diastole and pause, and as we have seen that the time occupied by these two periods is always less in an abnormally rapid heart, it follows, as a matter of course, that the quantity of nourishment must also be greatly curtailed in the muscles of such a heart. The pneumogastric nerve, therefore, at once becomes per. haps the greatest factor in the control of the nutrition of the heart muscle, for it is the cardio-inhibitory nerve of the organ, keeping down the rate of its action, so as to insure it the rest and nutrition which result from a full and complete diastole and pause, while it, at the same time, exerts moreover certain specific trophic influences over its muscular fiber; and it is, in fact, to the power possessed in varying degrees by certain remedies of stimulating this nerve that these remedies mainly owe their titles of heart tonics and stimulants; such, for example, as digitalis, which ranks certainly first, followed by strophanthus, convallaria, adonis vernalis, and several others-nux vomica being an exception in that it exerts its influence mainly on the cardiac ganglia themselves-and also nitroglycerin, whose most important action is that of a vasomotor dilator, whereby peripheral resistance is reduced, and the work ahead of the weak heart thus made easier.

With the foregoing facts in mind, we may now proceed to consider briefly the treatment of chronic heart disease. Cases in which compensation is in the formative stage, and those in which it is fully estab. lished, have already been alluded to. Those in which compensation is failing require, in addition to hygienic care and carefully regulated exercise, the administration of some of the well-known cardiac tonics with due regard to the needs and indications in each case. Where the failure of compensation is complete, so that the least effort leads to great distress, complete rest in the recumbent position must be insisted upon, and the exercise required for healthy general nutrition supplied in a passive manner by massage. In this way alone, the pulse-rate may be reduced from five to ten pulsations per minute, which even in five minutes would mean the sparing of a laboring heart many beats; so that absolute and complete rest in the recumbent posture can not be too strongly insisted upon in such cases to permit the flagging and almost worn-out organ to somewhat regain its strength, to be followed later on by carefully graduated exercise. But there comes a time in the history of these cases where the above plans of treat- ment fail to restore compensation, where the general anasarca, dyspnea, and the resulting great distress steadily increase, in spite of every effort on the part of the physician, and when dissolution seems to be inevitable. Fortunately, however, even at this critical juncture, we still possess one more remedy that may save life in a certain proportion of these most unpromising cases; and this remedy is the system of medicated baths and resistant movements, which have been so extensively developed and successfully applied by the brothers August and Theodore Schott at Nauheim, Germany, a small town in the Duchy of Hess, near Frankfort and Hamburg.

The credit, however, of the discovery of this method should not be given to them, but rather to Beneke, who first discovered it as far back as 1859 . Though from 1870 to 1890 , the Schott brothers were frequent contributors in the German press, and the springs were, during all this time, being visited by thousands of sufferers, it was not until 1894 that England gave the subject any serious thought, when presented in the Lancet by W. Bezley Thorne; since which time the method has there become very popular. Babcock of Chicago and Heineman of New York were the first to apply the method in this country, and were followed later on by some few others. In November, 1896, at the suggestion of Dr. William Osler of Baltimore, his first assistant, Dr. C. M. B. Camac, visited Nauheim to study thoroughly the treatment as carried on there, and his comprehensive report appeared soon afier in the Johns Hopkins Hospital Bulletin. So that you see the treatment is not new, but an old method which appears new because so long neglected.

According to Schott, these natural springs at Nauheim contain, among other ingredients, sodii chloridi 2 to 3 per cent. calcii chloridi 2 to 3 to the thousand, various salts of iron, and very large amounts of carbonic acid gas. These mentioned ingredients are the active agents in the bath, and their action is a reflex one. The carbonic acid gas entering directly into the skin, and the salts by imbibition, they all exert an influence on the cutaneous nerve-endings, which is carried to the nerve centers and results, first, in stimulation of the pneumogastric nerve with a resulting tonic influence on the heart and slowing of its rate of action; and, secondly, there is produced by these chemic ingredients also a reflex excitation of these terminal nerves in the skin, which results in a vaso. motor dilatation of the arteries of the skin and mus. cles; and as the skin and muscles are capable of containing as much blood as all the internal organs combined, we have thus a relief of internal congestions, and also a relief of blood tension ahead of a crippled heart. As a result of these influences on the circulatios, we have, in favorable cases, besides an amelioration of all the symptoms, an actual reduction in the size of the dilated heart, as is evidenced by a carrying inward of an outwardly displaced apex, and a reduction in the area of cardiac dullness on percussion.

These baths can be prepared artificially according to the ensuing formulæ, and are generally employed in the following six strengths:

Bath No. 1. Sodii Chloridi 4 lbs., Cal. Chloridi 6 oz. Bath No. 2. Sodii Chloridi 5 lbs., Cal. Chloridi 8 oz.

Bath No. 3. Sodii Chloridi $6 \mathrm{lbs}$, Cal. Chloridi $10 \mathrm{oz}$.

Sodii bicarb. $6 \mathrm{oz}, \mathrm{HCl} .7 \mathrm{oz}$.

Bath No. 4. Sodii Chloridi 7 lbs., Cal. Chloridi $10 \mathrm{oz}$. Sodii bicarb. $8 \mathrm{oz}$, HCl. $12 \mathrm{oz}$. 
Bath No. 5. Sodii Chloridi 9 lbs, Cal. Chloridi $11 \mathrm{oz}$. Sodii bicarb. 1 lb., HCl. $1 \mathrm{lb}$.

Bath No. 6. Sodii Chloridi, 11 lbs., Cal. Chloridi 12 oz. Soda bicarb. $1 \mathrm{lb}$., HCl. 2 lbs.

To the foregoing different strengths of these ingredients are added forty gallons of water. The bath is to be given every other day, preferably in the morn. ing, when the stomach is most apt not to be full.

Strength No. 1 is given as long as there is any im. provement. Should the case come to a stand-still, begin to lose ground, or if after three or four baths of No. 1 strength, there should be no improvement, then the next strength should be tried, and so on up to the third and fourth strengths. The last two strengths, however, are rarely used. The temperature of the first bath should be about 96 degrees F., decreased every third bath from one to three degrees, down to 82 degrees. The patient remains in the first bath five minutes, increasing two minutes every second or third bath until twenty or thirty minutes is reached.

If, during the course of the treatment, the patient should grow steadily worse, or if after fifty baths, there should be no improvement, the treatment should be stopped. The patient should be carefully watched during the entire bath, and upon the appearance of any great increase of dyspnea, or cyanosis, should be removed from the tub immediately, well rubbed and given some diffusible stimulant. A cup of hot milk, cocoa or bouillon should be administered before and after the bath. After the bath, the patient should be put to bed for an hour or two of rest. Ordinarily the effect of the bath is most grateful. Respiration and pulse both improve, and after leaving the tub the patient generally feels inclined to sleep. On alternate days the resistant movements, as introduced first by Schott, are administered. They are nineteen in number, and involve all the larger muscles of the body. They consist of slow movements executed by the patient and gently resisted by the operator. The movements are divided into different groups, as for arms, legs, trunk, hands, feet, etc. At first, only a few of these movements are given, which are to be afterward carefully increased according to the patient's ability to stand them. The object of these exercises is: 1 , they train the heart muscles; 2 , they cause more blood to pass through the muscular arteries, and thereby help the circulation of blood away from the heart; 3 , through the valves in the veins, they favor the venous current toward the heart; 4 , they improve general nutrition. In their adminis. tration, however, they must never cause any undue fatigue. They rest somewhat on the same principles as Oertel's system of mountain climbing.

As to the class of cases in which the baths and exercises are indicated, the reply would seem to be: in every case where there is failure of cardiac compensation, whether the result of valvular diseases, lesions of the kidney, or those affections primarily of the myocardium. They seem to accomplish most in cases of mitral regurgitation; less in aortic cases, and in the hearts of renal lesions. However, I believe the last class of maladies present a good field for the method in selected cases.

Statistics of results of this method of treatment seem as yet somewhat meager and difficult of attainment, in this country at least. On June 24, 1893, Dr. Robert H. Babcock of Chicago, a well-known authority on diseases of the heart, placed himself under Schott's care at Nauheim for disturbance of compensation, the result of a mitral stenotic lesion. In the report of his own case, published in the JoURnaL OF THE American Medical Association, November 11, 1893, he says that at the time he consulted Schott he was suffering with dyspnea on exertion, some cyanosis, a feeble pulse, but no edema. Schott diagnosed a mi. tral stenotic lesion. He received baths and movements from June 24 to July 29, 1893, and returned home free of symptoms, and in his own words, in excellent health. Camac has reported ten cases from the wards of Johns Hopkins Hospital in the June number, 1897, of this Hospital's Bulletin as follows:

\begin{tabular}{|c|c|c|c|c|}
\hline Name. & Diagnosis. & Treatment. & $\begin{array}{l}\text { Condition dur- } \\
\text { ing treatment. }\end{array}$ & Result. \\
\hline $\begin{array}{l}\text { A. H., colored.. } \\
\text { Mr. C . . . . } \\
\text { I. A. . . . } \\
\text { G. L. . . . . } \\
\text { G. S.. . . . . } \\
\text { B. C.. . . . } \\
\text { Miss B. . . . } \\
\text { W. W., colored } \\
\text { J. H.. . . . . } \\
\text { Mrs. L, . . . }\end{array}$ & $\begin{array}{l}\text { A ortic Insuff- } \\
\text { ciency. } \\
\text { Cardiac Dilata- } \\
\text { tion. } \\
\text { Chronic Nephri- } \\
\text { tis. } \\
\text { Mitral Stenosis. } \\
\text { Glycosuria and } \\
\text { Dilatation. } \\
\text { Dilatation and } \\
\text { Chro o i Ne- } \\
\text { phritis. } \\
\text { Dilatation and } \\
\text { Tachycardia. } \\
\text { Dilatation and } \\
\text { Sclerosis. } \\
\text { Mitral Insuff- } \\
\text { ciency. } \\
\text { Tachycardia. }\end{array}$ & 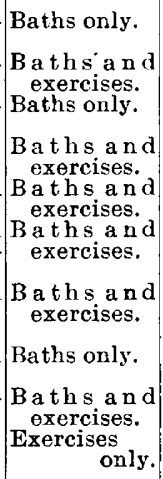 & $\begin{array}{l}\text { Improved. } \\
\text { Marked im- } \\
\text { provement. } \\
\text { No improve- } \\
\text { ment. } \\
\text { Marked im- } \\
\text { provement. } \\
\text { No improve- } \\
\text { ment. } \\
\text { No improve- } \\
\text { ment. } \\
\text { Improvement } \\
\text { only during } \\
\text { treatment. } \\
\text { Marked im- } \\
\text { provement. } \\
\text { Marked im- } \\
\text { provement. } \\
\text { Marked im- } \\
\text { provement. }\end{array}$ & $\begin{array}{l}\text { Death. } \\
\text { Death. } \\
\text { Death. } \\
\text { Deatl. } \\
\text { Noimprove- } \\
\text { ment. } \\
\text { Noimprove- } \\
\text { ment. }\end{array}$ \\
\hline
\end{tabular}

Summary: Four deaths; in two no improvement; in one, improvement during treatment only; and three continued improvement.

My cases comprise seven, with five deaths, one marked improvement during treatment and one complete recovery, understanding, of course, by recovery, not repair of valve damage, but simply complete restoration of cardiac compensation.

I desire, however, to state that' in none of these cases was the bath treatment begun until all other methods had been given a fair trial and had failed, and that five of the patients were inmates of our city hospital, placed at my disposal through the kindness of Dr. Otto Sutter, so that we must make allowance here for the kind of humanity that drifts into our public institutions, and for the kind of hygienic influences to which the patients are there exposed, as to shelter, food, air, etc., in the present temporary and unfatisfactory buildings our city hospital has been obliged to occupy since the tornado two years ago. Especially is this latter consideration important, for in one or two of my cases, I think the fatal result attributable in a measure to the draughts and chillings to which the patient was unavoidably exposed after the baths. The abbreviated notes of these cases are as follows:

Case 1.-F. B. male, aged 22, entered the City Hospital Dec. 2,1897 . Had symptoms of cardiac disease for the past three years ; for past four monthe failure of compensation has gradually increased, and is now complete, with general anasarca and great dyspnea. Diagnosis, mitral stenosis and regurgitation, small amount of albumin in urine. Given baths No. 1 strength on December 4 and 5 with apparently no improvement in his symptoms. Failure of compensation steadily increased. Patient died Dec. 9, 1898.

Case 2.-J. O'R. male, aged 35, entered the City Hospital Oct. 14,1897 . Diagnosis, mitral regurgitation; feet edematous, dyspnea marked on exertion; no renal lesion. Given baths (No. 1 and 2 strength) and exercises from June 27 to July 29,1898 , during which time the apex-beat changed from 9.75 $\mathrm{cm}$. on June 29 to $8.5 \mathrm{~cm}$. on July 18 to left of median line. Urine rose from 450 c.c. on June 29 to 2700 c.c. on July 29. 
Circumference of ankle was reduced from 29 to $27 \mathrm{~cm}$, dys. pnea had also greatly decreased and patient looked and felt much improved. Unfortunately, exposed to draught on night died July 31. But for such an unfortunate complication this case promised a good result.

Case 3.-A. W., male, aged 41, entered City Hospital Oct. 13, 1897. Had some cardiac symptoms for three years; considerable disturbance of compensation for past three months. Diag nosie, aortic regurgitation: no renal lesion. Given baths from October 26 to November 16 . Apex beat reduced from $16 \mathrm{~cm}$. on October 26 to $11.5 \mathrm{~cm}$. on November 12. On October 29, he was able to lie down, which he had been unable to do for two weeks. From November 3, however, he began again to fai and finally succumbed, November 22.

Case 4.--J. H., male, aged 45, entered City Hospital June 10, 1898. Diagnosis, double lesion of aortic and mitral orifices. Given baths and movements from June 29 to A ugust 17, urine increased from 325 c.c. July 7 to 1400 c.c. July 28 . A pex reduced from $10.5 \mathrm{~cm}$. June 29 to $9 \mathrm{~cm}$. A ugust 6. Appeared to improve somewhat up to about A ugust 1 , when edema increased, and patient gradually went downward toward a fatal termination.

Case 5.-W. McG., male, aged 32, entered the Hospital Aug 27, 1897. Diagnosis, mitral and aortic insufficiency. Died Sept. 20. Baths given from September 12 to September 17. Beyond a transient reduction of edema, and a change of apex beat from 13 to $11.25 \mathrm{~cm}$. the course of the disease did not seem to be in any way influenced. As is often the case in aortic regurgitation, the end in this case came suddenly, during an effort at getting from the bed to the bathroom.
Within one and one-half hours after the bath on April 4, 421 ounces of urine were passed. So marked, indeed, had been the improvement in every way in this case, that the patient unfortunately imagined himself a well man, and suggested discontinuance of treatment. Later on, symptoms recurred, and under treatment by other methods and in other hands he finally succumbed, some time, I believe, in the latter part of September.

Here then, in this case was certainly obtained a marked relief of symptoms for a considerable period of time, which perhaps, might have been greatly extended had the patient submitted his case entirely to his physicians. In the seventh and last case a result was obtained that, I think, you will grant me was truly ideal.

Case 7.--A. D. female, aged 17 years. Seen Jan. 30, 1898, at St. Mary's Infirmary, through the courtesy of Dr. W. A. McCandless. More or less heart symptoms since an attack of in termittent fever in 1891, which symptoms were aggravated by an attack of rheumatism, of one month's duration, in 1896 Entered hospital about Jan. 10, 1898, since which time had been steadily growing worse, in spite of most appropriate treatment until condition had become most pitiable. Edema of lower extremities very great. Had sinking spells in which she was every minute expected to expire; could not leave her chair day or night. Diagnosis, mitral regurgitation with complete failure of compensation; patient very anemic. Given baths and later on movements from February 1 to March 15, 22 baths in all. After second bath, on February 4, she spent a better

Chart for Case No. 7, Showing Method of Recording Observations.

Diagnosis.-Mitral Insufficiency with Complete Failure of Compensation.

\begin{tabular}{|c|c|c|c|c|c|c|c|c|c|c|c|c|c|c|c|c|c|c|c|c|}
\hline \multirow[b]{2}{*}{ Date, 1898.} & \multirow{2}{*}{\multicolumn{2}{|c|}{ 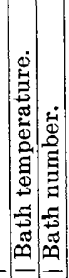 }} & \multicolumn{2}{|c|}{ Time. } & \multicolumn{2}{|c|}{ Before. } & \multicolumn{2}{|c|}{$\begin{array}{l}\text { First } \\
\text { half. }\end{array}$} & \multicolumn{2}{|c|}{$\begin{array}{l}\text { Second } \\
\text { half. }\end{array}$} & \multicolumn{2}{|c|}{$\begin{array}{l}\text { Imme. } \\
\text { diately } \\
\text { after. }\end{array}$} & \multicolumn{2}{|c|}{$\begin{array}{l}10 \text { min- } \\
\text { utes } \\
\text { after. }\end{array}$} & \multicolumn{3}{|c|}{$\begin{array}{l}\text { Point of maxi- } \\
\text { mum impulse } \\
\text { in inches. }\end{array}$} & \multicolumn{2}{|c|}{$\begin{array}{l}\text { Urine in } \\
24 \text { hours. }\end{array}$} & \multirow[b]{2}{*}{ Remarks. } \\
\hline & & & 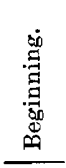 & 节 & 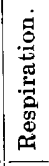 & $\stackrel{8}{3}$ & 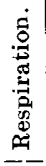 & 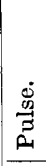 & 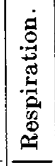 & م. & 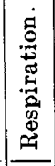 & 离 & 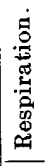 & $\frac{0}{3}$ & 营 & $\stackrel{8}{\Xi}$ & 离 & $\begin{array}{l}\vec{g} \\
0 \\
g \\
g\end{array}$ & 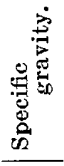 & \\
\hline February 1 & 98 & 1 & $3: 15$ & $3: 21$ & 30 & 130 & 44 & 138 & 40 & 138 & 34 & 136 & 28 & 132 & $5^{1 / 4}$ & $4 \frac{1 / 4}{4}$ & 4,4 & $266^{1 / 2}$ & 1020 & \\
\hline & 96 & 1 & $2: 50$ & $2: 57$ & 37 & 118 & 42 & 140 & 42 & 124 & 48 & 128 & 44 & 128 & $51 / 4$ & $41 / 2$ & & 26 & 1020 & Best night since entering hospital \\
\hline February 7 . & $\begin{array}{l}98 \\
99\end{array}$ & 1 & $2: 42$ & $2: 49$ & 23 & 105 & 32 & 126 & $\begin{array}{l}36 \\
32\end{array}$ & 114 & & & 20 & 110 & $41 \%$ & 4 & 4 & 28 & $\begin{array}{l}1025 \\
1025\end{array}$ & Can rest comfortably in recumbent posture \\
\hline $\begin{array}{l}\text { February } 9 . \\
\text { February } 11 .\end{array}$ & $\left|\begin{array}{l}9 z \\
92\end{array}\right|$ & 1 & $\begin{array}{l}3: 36 \\
2: 46\end{array}$ & $\begin{array}{l}3: 40 \\
2: 55\end{array}$ & $\mathbf{2 4}$ & $\begin{array}{l}110 \\
110\end{array}$ & $\begin{array}{l}28 \\
30\end{array}$ & 1100 & $\begin{array}{l}32 \\
24\end{array}$ & $\begin{array}{l}116 \\
118\end{array}$ & $\begin{array}{l}26 \\
16\end{array}$ & 114 & $\begin{array}{l}20 \\
17\end{array}$ & $\begin{array}{l}108 \\
110\end{array}$ & $\begin{array}{l}41 / 2 \\
41 / 8\end{array}$ & 4 & $\begin{array}{l}41 / 4 \\
4\end{array}$ & 28 & $\begin{array}{l}1025 \\
1030\end{array}$ & Patient asleep ten minutes after bath. \\
\hline February 14. & 92 & 1 & $3: 20$ & $3: 28$ & 15 & 114 & 22 & 120 & 22 & 120 & 18 & 116 & & 1000 & $41 / 4$ & $4^{1 / 4}$ & $4^{1 / 4}$ & 42 & 1010 & Slept well from 8 P.M. to 5 A.M. \\
\hline February 17. & & & $3: 03$ & $3: 14$ & 18 & 116 & . . & . . & 22 & 122 & 20 & 122 & 19 & 112 & $4 \frac{1}{2}$ & $4^{1 / 2}$ & $4 \frac{1}{4}$ & 38 & 1010 & Only now slight edema over tibiæ. \\
\hline February 21. & 90 & 2 & $3: 01$ & $3: 14$ & 18 & 110 & . & . & 22 & 111 & 20 & 111 & 19 & 108 & 4 & 4 & 4 & 42 & 1012 & \\
\hline February 24. & 88 & $\mid \frac{2}{n}$ & $2: 59$ & $3: 15$ & 26 & 85 & & & 23 & 98 & 26 & 105 & 24 & 98 & $3 \%$ & $3 \%$ & $35 / 8$ & 48 & 1010 & \\
\hline February $? 8$. & 90 & $\frac{2}{2}$ & $4: 08$ & $4: 24$ & 20 & 98 & 28 & 100 & 28 & 104 & 23 & 92 & 20 & 94 & & 4 & 4 & 43 & 1010 & . \\
\hline March 3. & $\begin{array}{l}88 \\
88\end{array}$ & 2 & $\begin{array}{l}2: 15 \\
4: 46\end{array}$ & $\begin{array}{l}2: 31 \\
5: 04\end{array}$ & 22 & $\begin{array}{r}100 \\
88\end{array}$ & 20 & $\begin{array}{l}97 \\
88\end{array}$ & $\begin{array}{l}25 \\
15\end{array}$ & 98 & 21 & 93 & 22 & 88 & 33 & 3 & $3^{3}$ & 35 & 1012 & \\
\hline & 88 & 3 & $\begin{array}{l}4: 40 \\
3: 01\end{array}$ & $\begin{array}{l}0.04 \\
3: 19\end{array}$ & 24 & 98 & 21 & 93 & $\begin{array}{l}15 \\
22\end{array}$ & $\begin{array}{l}96 \\
98\end{array}$ & 20 & $\begin{array}{l}y_{1} \\
91\end{array}$ & 22 & 88 & $3 \%$ & $3 \%$ & $3 \%$ & 40 & 1010 & \\
\hline 12 . & 88 & 2 & $2: 56$ & & 20 & 89 & 22 & 87 & 22 & 90 & 20 & $8 \tilde{3}$ & 20 & 82 & $3 \%$ & $3^{3}$ & $3 \%$ & 45 & 1012 & Pulse regular. \\
\hline & 90 & 2 & $1: 40$ & & 22 & 82 & 24 & 85 & 22 & 90 & 21 & 74 & 21 & 88 & $33 / 4$ & $33 / 4$ & $3 \%$ & & $\cdots$ & $\begin{array}{l}\text { Digitalis stopped, owing to symptoms of } \\
\text { gastric irritation. }\end{array}$ \\
\hline March $21 \ldots$ & 89 & 9) 2 & $3: 04$ & $3: 22$ & 18 & 91 & 22 & 97 & 19 & 93 & 19 & 90 & 20 & 80 & $33 / 4$ & $33 / 4$ & $33 / 4$ & . & .. & $\begin{array}{l}\text { Apex-beat well defined; relative dulness at } \\
\text { mammary line; entirely free of symptoms. }\end{array}$ \\
\hline
\end{tabular}

Case 6.-H. S., male, aged 42 years; seen in consultation night than she had since entering hospital. February 10, slept with Dr. John P. Bryson, Feb. 27, 1898. History of more or less dyspnea, dating back for five or six months. Heart enlarged and dilated, but impossible to determine exact outlines or position of apex, due to amount of adipose tissue and feebleness of heart's action. Pulse sclerotic, no cardiac murmurs : urine contained on several examinations from .25 to .5 per cent albumin, and a few byaline and granular casts. Lower extremities enormously edematous; has been confined to house for weeks, and for about a week has been unable to lie down in bed. What little sleep he has had, has been in snatches while sitting up in an easy chair. Diagnosis, chronic interstitial nephritis, artero-capillary sclerosis, hypertrophied and dilated heart. Given baths and movements from March 2 to April 20,1898, during which time compensation was sufficiently restored that patient obtained a good rest at night in recumbent posture; could get in and out of tub by himself, when at first he had to be lifted. All edema completely disappeared except some occasional slight puffiness of feet. He was soon able to get out for a drive and get down again on a visit to his place of business. Amount of urine for twenty-four hours, which on March 5 was only 13 ounces, increased to 87 ounces, as the maximum quantity on April 4. In fact, the effect of the treatment on the secretion of urine seemed almost, in this case, marvelous. For example, on April 2, patient urinated just before bath, and in thirty minutes after the bath passed 18 ounces, and within an.hour passed altogether 22 ounces. well from 10 P.M. till 5 A.M. ; February 15, had been sleeping from seven to eight hours without awakening, since last note. February 28 had been sleoping all night and eating everything offered her. Could now get about the wards and halls. March 16. Patient menstruated today, first time in two years. Pulse was reduced from 140 February 4 to 70 March 15 ; respiration from 42 to 20 in the same time; apex-beat from $5 \frac{1}{4}$ to $3 \frac{1}{4}$ inches. Urine increased from 26 ounces on February 4 to 53 ounces on February 13: entire disappearance of edema; on leaving hospital, patient was entirely free of symptoms.

She was at my office on July 10 , when she had gained 16 pounds in weight, weighing 134 pounds, which is more than she had ever weighed before. She appeared the picture of health; had been menstruating regularly every month since leaving hospital. Had also been completely free of symptoms, and had been able without discomfort to remain steadily at her work, that of a bookbinder.

One very striking effect of the bath in this case was the quieting, soothing influence exerted, causing the 1 She was at my office again on Nov. 20,1898 , when she was perfectly
well and stated she had been so since her last visit. She stated she then well, and stated she 
patient as soon as put to bed to fall almost invariably into a tranquil nap of one or two hours' duration, from which she awoke refreshed and strengthened.

Of the beneficial result of the bath treatment in this case, I am satisfied beyond any question, and had the girl not received the baths and movements, she would have, I am thoroughly convinced, succumbed to the heart affection.

In estirating the efficacy of the method in the preceding cases, we must take into consideration besides what I have already alluded to, the fact that three out of the five fatal cases had aortic regurgitation, and it has been the observation of the advocates of the method that this class of cases have not responded well to the treatment. One of the remaining fatal cases had mitral stenosis, which is also notably an unfavorable lesion under any plan of treatment. Case 2, which was one of pure mitral regurgitation, gave every promise of a favorable result before the onset of pneumonia, which complication might, I think, have been avoided under different surroundings; nor can the fatal result in Case 6, that of nephritis and arteriosclerosis, be attributed to the bath treatment, for under it the patient's condition had improved marvelously, and the end only came after he had abandoned the method for some time; so that properly speaking we should only classify four of my seven cases as apparently not being at all controlled by the bath method. On the other hand, it must be understood that reliance was by no means placed on the bath and exercises alone, to the exclusion of the older and better-known remedies, which were employed as the indications arose for their use, in conjunction with the bath treatment.

A brief summary of the foregoing seven cases with results is as follows:

\begin{tabular}{|c|c|c|c|c|}
\hline 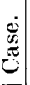 & Diagnosis. & $\begin{array}{l}\text { Treat- } \\
\text { ment. }\end{array}$ & $\begin{array}{l}\text { Condition } \\
\text { during } \\
\text { treatment. }\end{array}$ & Result. \\
\hline 1 & $\begin{array}{l}\text { Mitral stenosis and regurgita- } \\
\text { tion }\end{array}$ & Bathsonly & No improve- & Death. \\
\hline 2 & Mitral regurgitation. . & $\begin{array}{r}\text { Baths and } \\
\text { exercises. }\end{array}$ & $\begin{array}{l}\text { M a rked im- } \\
\text { provement... }\end{array}$ & Death. \\
\hline 3 & Aortic regurgitation. & Baths only: & Improvement & Death. \\
\hline 4 & Double aortic and mitral & $\begin{array}{l}\text { Baths and } \\
\text { exercises. }\end{array}$ & $\begin{array}{l}\text { Improvement } \\
\text { for a while. }\end{array}$ & Death. \\
\hline 5 & $\begin{array}{c}\text { Aortic and mitral regurgita- } \\
\text { tion }\end{array}$ & Baths only. & No improve & Death. \\
\hline 6 & $\begin{array}{l}\text { Chronic interstitial nephritis, } \\
\text { arterio-capillary sclerosis } \\
\text { dilated and hypertrophied }\end{array}$ & $\begin{array}{l}\text { Baths and } \\
\text { exercises. }\end{array}$ & $\begin{array}{l}\text { Marked im- } \\
\text { provement }\end{array}$ & $\begin{array}{l}\text { Death some } \\
\text { time after } \\
\text { abandoning }\end{array}$ \\
\hline 7 & Mitral regurgitation. & $\begin{array}{l}\text { Baths and } \\
\text { exercises. }\end{array}$ & $\begin{array}{c}\text { Marked im- } \\
\text { provement }\end{array}$ & Well. \\
\hline
\end{tabular}

But even a plan of treatment that will save one life and bring complete, though temporary, relief of all symptoms in another must be certainly looked upon as a valuable aid to us in dealing with a group of cases such as those just described, all which were completely uncontrollable by any of the older methods; while, on the other hand we have just seen that Camac was fortunate enough to save three out of his series of ten cases.

In conclusion, I desire to acknowledge my indebtedness to the valuable contributions of Brunton, Babcock, Camac and Gibson; also to thank Dr. Sutter and his corps of physicians at the City Hospital, especially Drs. Dean and Amyx, for their kind co-operation, and Drs. Hoge and Bryan for much valuable assistance in supervising the work in my absence.

116 North Grand Avenue.
LOOMIS SANITARIUM FOR CONSUMPTIVES. ANNUAL REPORT.

BY J. EDWARD STUBBERT, M.D.

PHYSICIAN IN CHARGE.

The following report represents the work of the Loomis Sanitarium, located at Liberty, Shawangunk mountains, Sullivan county, N.Y., for the year ending Nov. 1, 1898:

The number of patients in the sanitarium Nov. 1, 1897, was 78 ; admitted since, 126 ; total, 204 . The number of patients in the sanitarium Nov. 1,1898 , was 47 ; patients discharged cured having numbered 28, discharged with disease arrested 11, discharged improved 67, diseharged who remained stationary 6 , discharged unimproved 41 , while 4 had died.

As to the condition of patients when admitted, 17 were in the incipient stage, ${ }^{158}$ in the incipient stage with bacilli, 102 moderately advanced, ${ }^{2}$ and 27 far advanced ${ }^{3}$.

Class 1 (patiente who remained three months or less in the sanitarium). -The condition when admitted showed: Incipient stage without bacilli, 9 ; incipient stage with bacilli, 23 ; mod erately advanced, 31 ; far advanced, 12 ; total 75 . The condition when discharged showed: Cured, 10 ; disease arrested in 5 ; improved, 35 ; stationary, 4 ; unimproved, 19 ; deaths, 2 ; total, 75 .

Class 2 (patients who remained in the sanitarium more than three months)--The condition when admitted showed: Incipient stage without bacilli, 4; incipient stage with bacilli, 24 ; moderately advanced, 44 ; far advanced, 10 ; total, 82 . The condition when discharged showed : Cured, 18 ; disease arrested in 6 ; improved, 32 ; etationary, 2 ; unimproved, 22 ; deaths, 2 ; total, 82

The number of patients whose sputum contained bacilli on admission was 187 , with 37 whose sputum was free from bacilli on discharge, while 53 had hemorrhage before admission, 10 had hemorrhages in the sanitarium, 153 gained in weight, 25 remained stationary in weight, and 26 lost weight. The average gain per week per patient was two pounds, the average lose per week per patient was one pound, the greatest monthly gain was fourteen pounds, the greatest monthly loss ten pounds, and the greatest gain for one patient thirty pounds.

During the year there were in the infirmary 83 patients, of whom 12 were in the infirmary twice.

A summary of the condition of patients still in the sanitarium shows that the bacilli disappeared in 3 cases, diminished in number in 11, while cough decreased in 32 and disappeared in 2 cases, and the physical signs improved in 33, weight was gained in 38 cases, remained stationary in 3 , and was lost in 6.

By comparing these figures with my annual report for 1897, published in the Philadelphia Medical Journal of March 12, 1898, p. 467, the following in. crease in good results among patients discharged during these two years will be noted: During the first year 8 per cent. of the patients discharged had lost their tubercle bacilli; during the past year 23 per cent. of those discharged had lost their tubercle bacilli. During the first year 73 per cent. of those discharged gained in weight, while during the past year 97 per cent. of those discharged had gained in weight. During the first year 13 per cent. of those discharged were cured, while during the past year 17 per cent. of those discharged were cured. During the first year 10 per cent. of those discharged had their disease arrested, while during the past year 7 per cent. had their disease arrested. It is interesting to note that of those patients discharged after a residence of three months or less at the sanitarium, 6 per cent. were cured, while among those remaining longer than three months, 11 per cent. were cured.

The basis of treatment in all cases has been climatic, hygienic and dietetic. The climate of Liberty is well adapted to the treatment of tuberculosis throughout the year, but there is even more marked

1 Incipient stage.-Slight localized involvement of lung, with little or o constitutional disturbances.

2 Moderately advanced.-More general consolidation of lung, with stitutional disturbances and beginning of softening, or single cavity. 3 Far advanced.-Softening and excavation, with marked con. tional disturbances. 